\author{
AlicJA Binkowska ${ }^{1}$, Aneta BRZEZICKA ${ }^{1,2}$ \\ ${ }^{1}$ Instytut $i$ Wydzial Psychologii \\ SWPS Uniwersytet Humanistycznospoleczny \\ Chodakowska 19/31, 03-815 Warszawa \\ ${ }^{2}$ Cedars-Sinai Medical Center \\ 8700 Beverly Blvd, Los Angeles, CA 90048, USA \\ E-mail: abinkowska2@st.swps.edu.pl \\ Aneta.Brzezicka@cshs.org
}

\title{
WPEYW MARIHUANY NA AKTYWNOŚĆ ELEKTRYCZNĄ MÓZGU
}

\section{WSTEP}

Marihuana jest obecnie jedna $z$ najpopularniejszych i najczęściej zażywanych substancji psychoaktywnych na świecie (DEGENHARDT i współaut. 2008). Na przestrzeni ostatnich lat diametralnie zmienił się status społeczno-prawny tej substancji - obserwujemy tendencje legalizacyjne (użytku rekreacyjnego i medycznego marihuany), pojawiły się możliwości prowadzenia badań naukowych z użyciem marihuany, a zarazem znacznie wzrosło zainteresowanie społeczne rzetelna wiedza o jej wpływie na organizm i zachowanie człowieka. Celem artykułu jest przybliżenie czytelnikowi wiedzy na temat wpływu marihuany na procesy biochemiczne oraz aktywność elektryczna mózgu u zwierzat i ludzi.

Konopie indyjskie, $z$ których produkuje się marihuanę, zawieraja ponad 140 różnych związków aktywnych - kannabinoidów (HANUŠ i współaut. 2016), z których najlepiej poznane to tetrahydrokannabinol (ang. $\Delta$ 9-tetrahydrocannabinol, THC) i kannabidiol (ang. cannabidiol, CDB) (GAONI i MECHOULAM 1964, MECHOULAM i współaut. 2002). W niniejszym artykule będziemy omawiać efekty dotyczace przede wszystkim THC. Kannabinoidy działaja na układ endokannabinoidowy, który odgrywa istotna rolę w utrzymaniu homeostazy organizmu oraz w procesach neuroplastyczności, włączajac w nie neurogenezę (EGERTON i współaut. 2006, KATONA i FREUND 2012, BEFORT 2015). W skład układu endokannabinoidowego wchodzą dwa typy receptorów kannabinoidowych: CB1 i CB2 (ABOOD i MARTIN 1996, AXELROD i FELDER 1998) oraz endokannabinoidy (wytwarzane przez organizmy ludzi i zwierzat): anandamid i 2-arachidonyloglicerol (2-AG). Zarówno endokannabinoidy, jak i egzokannabinoidy (pochodzace $z$ zewnątrz, głównie THC i CDB) działaja za pośrednictwem receptorów CB1 i CB2. Receptory CB2 sa zlokalizowane w tkankach obwodowych, głównie na powierzchni komórek układu immunologicznego oraz w ośrodkowym układzie nerwowym, m.in. na komórkach mikrogleju (STELLA 2004). Rozproszenie receptorów kannabinoidowych w całym organizmie wyjaśnia wielokierunkowe działanie kannabinoidów. W tym przeglądzie skoncentrujemy się na wpływie kannabinoidów na mózg, gdzie kluczową rolę odgrywa aktywacja receptorów CB1. Największe zagęszczenie receptorów CB1 występuje w obszarach mózgu zwiazanych z procesami motywacyjnymi, poznawczymi, motorycznymi oraz zwiazanymi $z$ funkcjonowaniem układu nagrody. W skład tych obszarów wchodza przede wszystkim czołowe rejony kory oraz korowe obszary limbiczne, hipokamp, ciało migdałowate, móżdżek, wzgórze i zwoje podstawy mózgu (HERKENHAM i współaut. 1990) (Ryc. 1).

Endokannabinoidy, anandamid i 2-arachidonyloglicerol, pobudzając aktywność receptorów CB1, odgrywaja istotna rolę w modulowaniu przekaźnictwa synaptycznego. W normalnych warunkach (bez obecności THC) 
CB1 present:

\section{1. brain}

2. lungs

3. vascular system

4. muscles

5. gastrointestinal tract

6. reproductive organs

\section{CB2 present}

1. spleen

3. skin

$\mathrm{CB} 1+\mathrm{CB} 2$ present

1. immune system

2. liver

3. bone marrous

4. pancreas
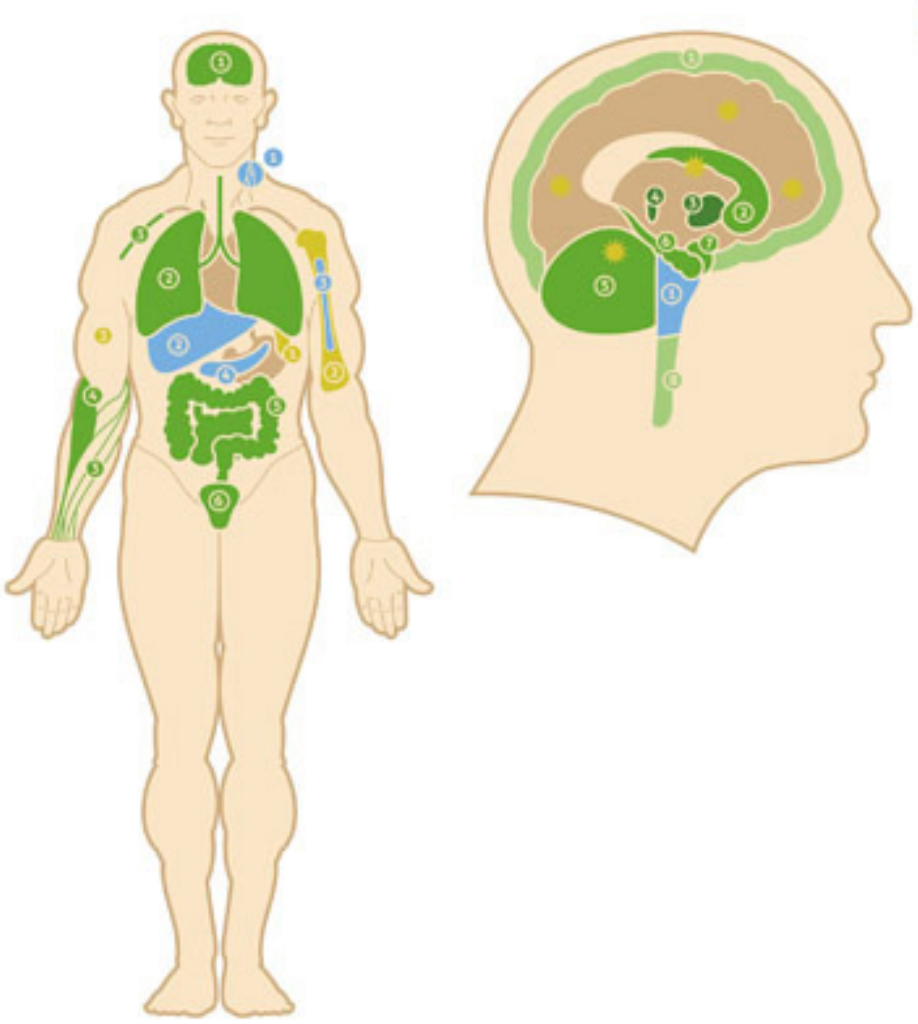

CB1 present:

1. cortex

2. caudate nucleus

and putamen

(nucleus acumbens)

3. basal ganglia

4. hypothalamus

5. cerebelum

6. hippocampus

7. amygdala

8. spinal cord

CB2 present

gliat cells

$\mathrm{CB} 1+\mathrm{CB} 2$ present

1. brainstem

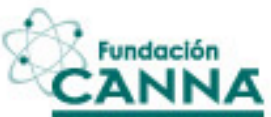

Ryc. 1. Występowanie receptorów CB1 i CB2 w organizmie człowieka.

Tłumaczenie: brain - mózg, lungs - płuca, vascular system - układ naczyniowy, muscles - mięśnie, gastrointestinal tract - przewód pokarmowy, reproductive organs - narządy rozrodcze, spleen - śledziona, bones - kości, skin - skóra, immune system - układ odpornościowy, liver - bone marrow - szpik kostny, pancreas - trzustka, cortex - kora mózgowa, caudate nucleus - jądro ogoniaste, putamen - skorupa, nucleus accumbens - jądro półleżacce, basal ganglia - zwoje podstawy, hypothalamus - podwzgórze, cerebellum - móżdżek, hippocampus - hipokamp, amygdala ciało migdałowate, spinal cord - rdzeń kręgowy, glial cells - komórki glejowe, brainstem - pień mózgu. (Oryginalna rycina Fundacji Canna, za zgoda).

endokannabinoidy te sa uwalniane przez neurony i działaja na receptory CB1 umiejscowione na zakończeniach synaptycznych neuronów GABAergicznych i glutaminergicznych, co skutkuje sygnalizacja wsteczna (ang. retrograde signaling) (Ryc. 2). Taki rodzaj komunikacji między neuronami oznacza, że sygnał przemieszcza się w odwrotnym kierunku, $Z$ neuronu postsynaptycznego do presynaptycznego, i działa hamujaco na neurony uwalniające przekaźniki ( $z$ błony presynaptycznej): kwas gammaaminomasłowy (GABA), kwas glutaminowy, noradrenalinę, serotoninę, acetylocholinę i dopaminę (PACHER i współaut. 2006, Russo i GuY 2006). W wyniku tej sygnalizacji wstecznej nastepuje zmniejszenie uwalniania neuroprzekaźników. Receptory CB1 pełnią więc funkcję neuromodulatora, ich aktywacja powoduje tłumienie hamowania postsynaptycznego przez zmniejszenie uwalniania kwasu gammaaminomasłowego (GABA) lub pobudzenia - przez zmniejszenie uwalniana gluta- minianu z zakończeń presynaptycznych. Ta krótkoterminowa plastyczność, powodowana aktywacja receptora CB1, nazywana jest odpowiednio indukowanym przez depolaryzację tłumieniem hamowania (ang. depolarization-induced suppression of inhibition, DSI) lub indukowanym przez depolaryzację tłumieniem pobudzenia (ang. depolarization-induced suppression of excitation, DSE) (ZIMMERMANN i współaut. 2019).

Podstawowy zwiazek psychoaktywny w marihuanie - THC - jest agonista ${ }^{1}$ receptorów CB1; pobudza ich aktywność, podobnie jak endokannabinoidy, jednak znacznie silniej, mniej selektywnie oraz przez dłuższy czas, zaburzając przy tym uwalnianie endokannabinoidów oraz, w efekcie, równowage układu endokannabinoidowego. To właśnie aktywacja receptorów CB1 odpowiada

${ }^{1}$ agonista - substancja, która przyłącza się do receptora i powoduje jego uaktywnienie (ABOOD i MARTIN 1996). 


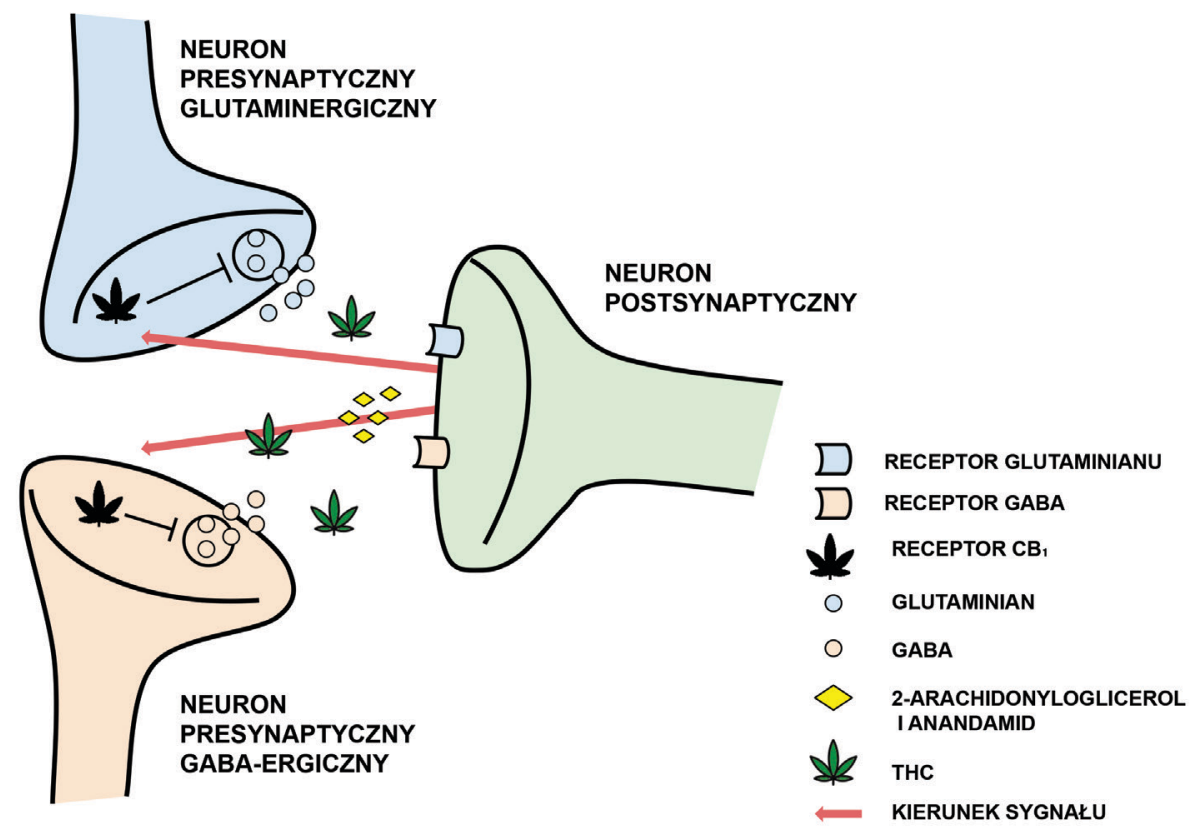

Ryc. 2. Schemat sygnalizacji wstecznej, w której biorą udział endogenne kannabinoidy i THC.

Endokannabinoidy (anandamid i 2-AG) są uwalniane przez neurony postsynaptyczne i działaja na receptory CB1 umiejscowione na zakończeniach synaptycznych sąsiadujących neuronów GABAergicznych i glutaminergicznych. Aktywacja receptorów CB1 prowadzi do zahamowania uwalniania neuroprzekaźników. THC zaburza ten proces - przyłączając się do receptorów CB1, pobudza je znacznie silniej oraz mniej selektywnie przez dłuższy okres czasu niż endokannabinoidy, hamując uwalnianie neuroprzekaźników i zaburzając równowage systemu endokannabinoidowego.

za powszechnie znane efekty działania marihuany, które obejmuja przede wszystkim łagodna euforię, zmiany percepcji zmysłowej i niewielka amnezję. Badania pokazuja, że poczucie subiektywnego tzw. „haju”, będace natychmiastowym efektem palenia marihuany, u zdrowych osób dorosłych może być skutecznie zablokowane przez wcześniejsze podanie antagonisty receptorów CB1 - rimonabantu (HUEsTIS i współaut. 2001). Co istotne, występuje tu silna zależność od dawki: niskie dawki THC prowadza do mieszanki efektów stymulujących, po czym następuja efekty uspokajajace, natomiast przy wyższych dawkach sa to efekty jedynie uspokajające (AMERI 1999). Użytkownicy rekreacyjni najczęściej poszukuja produktów z wysoka zawartością THC (główny związek psychoaktywny), użytkujący $z$ zaleceń medycznych przyjmuja produkty o różnej zawartości poszczególnych kannabinoidów - moga one zawierać wysokie dawki THC, CBD, bądź innych związków aktywnych.

Mechanizmy, za pośrednictwem których działa CBD, nie sa dotąd dokładnie znane, natomiast wiemy, że jest ich kilka. Kannabidiol bardzo słabo wiąże się $z$ receptorami kannabinoidowymi, jednak jest $\mathrm{w}$ stanie przeciwdziałać efektom THC, nawet jeśli występuje w bardzo małych stężeniach. CBD zatrzymując rozkład anandamidu, potęguje i wydłuża jego działanie (LIGRESTI i współaut.
2006), co w efekcie zapobiega oddziaływaniu THC na receptory CB1. Kannabidiol jest także agonista receptorów serotoninowych (RUSso i współaut. 2005), co może tłumaczyć niektóre antypsychotyczne i przeciwlękowe efekty jego działania (CAMPOS i GUIMARÃES 2008). Wpływając na wewnątrzkomórkowa zawartość wapnia, CBD najprawdopodobniej chroni neurony przed potencjalnie neurotoksycznym działaniem THC (DEMIRAKCA i współaut. 2011). Generalnie, kannabidiol pozostaje bez wplywu na normalne procesy fizjologiczne, jednak, kiedy jakiś bodziec lub inny kannabinoid zachwieje równowage systemu endokannabinoidowego, wówczas zaczyna działać w celu jej przywrócenia (AlGER i KIM 2011).

Istnieją różne drogi zażywania marihuany. Najpopularniejsza metoda jest palenie skrętów $z$ samej marihuany lub mieszanej $z$ tytoniem, jednak można także zażywać ja doustnie $\mathrm{w}$ formie olejków zawierających stężone ilości określonych kannabinoidów, przez waporyzacje lub $\mathrm{w}$ postaci przetworów kulinarnych. Behawioralne efekty działania marihuany zależą od szeregu czynników, takich jak: sposób podania (HINDOCHA i współaut. 2015, CURRAN i współaut. 2016), dawka (CAlabrese i Rubio-CASillas 2018), oczekiwania osoby zażywającej (METRIK i współaut. 2012) czy podatność genetyczna na wysta- 
pienie określonych efektów (MORGAN i współaut. 2016).

\section{WPEYW MARIHUANY NA PROCESY BIOCHEMICZNE W MÓZGU}

$Z$ badań przeprowadzonych na zwierzętach wiemy, że zażywanie THC prowadzi do zmian w strukturach mózgu charakteryzujacych sie największym zagęszczeniem receptorów $\mathrm{CB} 1$ : hipokampie, ciele migdałowatym i korze. Zmiany te zwiazane sa $z$ redukcja liczby synaps, zmniejszeniem ciał komórek i długości dendrytów (HEath i współaut. 1980, SCALLET i współaut. 1987, LANDFIELD i współaut. 1988, CHAN i współaut. 1998, DoWNER i współaut. 2001).

Kannabinoidy wpływaja również w złożony sposób na neurotransmisję. Marihuana (i szerzej - agoniści receptora CB1), podobnie jak inne substancje psychoaktywne, wpływa na biochemię układu mezolimbicznego, prowadzac do zwiększonego uwalniania dopaminy oraz zmniejszonego uwalniania GABA i glutaminianu $\mathrm{w}$ jądrze półleżącym (CHEN i współaut. 1993, TANDA i współaut. 1997, HOFFMAN i LUPICA 2001, PISTIS i współaut. 2002, CHEer i współaut. 2004). Opisane efekty, wraz ze zwiększonym uwalnianiem peptydu opioidowego w jądrze półleżącym, najprawdopodobniej przyczyniają się do natychmiastowego, nagradzajacego działania THC (MANZANARES i współaut. 1998, VALVERDE i współaut. 2001). Natomiast przy dłuższej ekspozycji na THC, u zwierzat zaobserwowano zaburzenia funkcjonowania połączeń w układzie nagrody, zwiazane $\mathrm{z}$ redukcja zagęszczenia komórek dopaminergicznych w polu brzusznym nakrywki (HigUERA-MATAS i współaut. 2010) oraz zwiększona aktywność neuroprzekaźnictwa zwiazanego ze stresem uwalnianie dynorfiny w jadrze półleżacym i czynnika uwalniającego kortykotropinę (ang. corticotropin-releasing factor, CRF) w ciele migdałowatym. Opisane deficyty w szlaku mezolimbicznym moga przyczyniać się do negatywnych stanów emocjonalnych i obniżonego funkcjonowania systemu nagrody, które sa bezpośrednio związane $z$ występowaniem objawów odstawiennych (DE FONSECA i współaut. 1997, CABERLOTTO i współaut. 2004, PISANU i współaut. 2006).

Endokannabinoidy i egzokannabinoidy, za sprawa dużego zagęszczenia receptorów $\mathrm{CB} 1 \mathrm{w}$ obszarach mózgu funkcjonalnie odpowiadających za kontrolę ruchu (móżdżku oraz jadrach podstawy), prowadza do obniżenia aktywności ruchowej (HERKENHAM i współaut. 1990, MAILLEUX i VANDERHAEGHEN 1992). Aktywność ruchowa zależy od równowagi układów hamujących i pobudzajacych, modulowanej przez endogenne kannabinoidy oddziaływujace na receptory CB1. Kannabinoidy obniżaja aktywność ruchowa przez hamowanie wychwytu zwrotnego GABA na zakończeniach neuronów łączacych prążkowie $z$ gałka blada oraz istota czarna, hamujac wychwyt zwrotny dopaminy $\mathrm{w}$ prażkowiu $\mathrm{i}$ redukując uwalnianie glutaminianu $\mathrm{w}$ jadrze niskowzgórzowym, co blokuje generowanie potencjałów czynnościowych $\mathrm{w}$ istocie czarnej (AMERI 1999). Zaburzenia funkcjonowania receptorów kannabinoidowych $\mathrm{w}$ obszarach ruchowych sa zwiazane $z$ chorobami neurodegeneracyjnymi, takimi jak choroba Parkinsona czy Huntingtona (GLASS i współaut. 1993, SAÑUdO-PEÑa i współaut. 1998).

Kannabinoidy wpływaja również na funkcje poznawcze i pamięć, co wiąże się $z$ dużym zagęszczeniem receptorów CB1 w hipokampie (HERKENHAM i współaut. 1990). Badania przeprowadzone na zwierzętach pokazuja, że agoniści receptorów CB1 (w tym endogenne kannabinoidy), hamuja utrwalanie długotrwałego pobudzenia synaptycznego (ang. long-term potentiation, LTP), uważanego za podstawowy mechanizm plastyczności synaptycznej (ABUSH i AKIRAV 2010) i podłoże mechanizmu pamięci. Dzieje się tak przez tłumienie uwalniania glutaminianu, acetylocholiny i noradrenaliny $\mathrm{w}$ hipokampie (SHEN i współaut. 1996, GIFFORD i współaut. 1997, SCHLICKER i współaut. 1997).

Większość opisanych powyżej efektów zaobserwowano $\mathrm{i}$ badano u zwierzat, jednak zaburzenia $\mathrm{w}$ budowie i pracy mózgu związane $z$ używaniem kannabinoidów stwierdzono także u ludzi, szczególnie w miejscach dużego zagęszczenia receptorów CB1 i, podobnie jak obserwujemy $w$ badaniach na zwierzętach, w obszarach funkcjonalnie powiązanych $z$ ruchem, pamięcia $i$ procesami emocjonalnymi (YÜCEL i współaut. 2007, LORENZETTI i współaut. 2016).

\section{WPŁYW KANNABINOIDÓW NA AKTYWNOŚC ELEKTRYCZNA MÓZGU}

Zmiany w pracy mózgu spowodowane zażywaniem marihuany można badać, obserwując aktywność elektryczną mózgu (oscylacje aktywności neuronalnej) przy użyciu elektroencefalografii (EEG). Oscylacje EEG (fale mózgowe), to rytmiczna aktywność neuronalna $\mathrm{w}$ ośrodkowym układzie nerwowym, która wyłania się $\mathrm{z}$ synchronizacji dużych populacji neuronów (BAŞAR i współaut. 2004). Uważa się, że oscylacje neuronalne, tradycyjnie klasyfikowane w zakresie pięciu przedziałów częstotliwości: delta, theta, alfa, beta i gamma, sa generowane $\mathrm{w}$ różnych obszarach mózgu i obrazuja mechanizmy obserwowanych procesów poznawczych (BAŞAR i współaut. 1999, Pfurtsheller i DA 
Tabela 1. Charakterystyka wyróżnionych pasm częstotliwości w aktywności elektrycznej mózgu (EEG).

\begin{tabular}{|c|c|c|}
\hline Podstawowe pasma & Zakres częstotliwości & Rola \\
\hline delta & $0,5-4 \mathrm{~Hz}$ & $\begin{array}{l}\text { - jest związane ze snem (DE GENNARO i współaut. 2000); } \\
\text { - odgrywa rolę w przetwarzaniu bodźców emocjonalnych (BHATTA- } \\
\text { CHARYA i PETSCHE 2002), procesach motywacyjnych (KNYAZEV 2012), } \\
\text { uwagowych oraz w hamowaniu behawioralnym (PUTMAN 2011). }\end{array}$ \\
\hline theta & 4-7 Hz & $\begin{array}{l}\text { - jest związane z działaniem pamięci roboczej i wysiłkiem poznaw- } \\
\text { czym; } \\
\text { - odgrywa bardzo istotną rolę w procesach uwagi i integracji infor- } \\
\text { macji czuciowo-ruchowej oraz kontroli ruchów dowolnych (BLAND } \\
\text { 1986, BLAND i COLOM 1993, VINOGRADOVA 1995). }\end{array}$ \\
\hline alfa & $8-12 \mathrm{~Hz}$ & $\begin{array}{l}\text { - jest ujemnie skorelowane } z \text { metabolizmem komórek nerwowych, } \\
\text { występuje głównie w stanach relaksu; } \\
\text { - wiąże się z procesami percepcyjnymi i uwagowymi oraz pamię- } \\
\text { cią roboczą i długotrwała (SAUSENG i współaut. 2005), wyobraźnia } \\
\text { wzrokową, mentalnymi kalkulacjami (PALVA i współaut. 2005, PA- } \\
\text { LVA i PALVA 2007) } \\
\text { - niektóre badania sugeruja związek oscylacji alfa z procesami ha- } \\
\text { mowania (HANDEL i współaut. 2011). }\end{array}$ \\
\hline beta & $13-30 \mathrm{~Hz}$ & $\begin{array}{l}\text { - jest zwiąane z aktywnością poznawcza, a szczególnie z koncen- } \\
\text { tracją uwagi, pamięcią, uwaga wzrokowa (WRÓBEL 2000) } \\
\text { - odgrywa także istotna rolę w czynnościach ruchowych, zwłaszcza } \\
\text { w kontroli ruchowej (SALENIUs i HARI 2003) i przygotowaniu ruchu } \\
\text { (SANES i DONOGHUE 1993). }\end{array}$ \\
\hline gamma & $30 \mathrm{~Hz}<$ & $\begin{array}{l}\text { - wiąże się z wyższymi procesami poznawczymi, szczególnie z in- } \\
\text { tegracją informacji z poszczególnych modalności zmysłowych (GRAY } \\
\text { 1994), pamięcia (FELL i współaut. 2001), ukierunkowaniem uwagi } \\
\text { (FRIEs i współaut. 2001) i "świadomym” doświadczeniem (LLINÁs i } \\
\text { współaut. 1998, VARELA i współaut. 2001) } \\
\text { - odgrywa również istotna rolę w kodowaniu i odtwarzaniu śladów } \\
\text { pamięciowych (BRAGIN i współaut. 1995, LISMAN i IDIART 1995). }\end{array}$ \\
\hline
\end{tabular}

Silva 1999). Charakterystyka poszczególnych fal mózgowych zawarta jest w Tabeli 1 .

Badanie EEG polega na rozmieszczeniu elektrod pomiarowych na powierzchni głowy, a w wyjątkowych okolicznościach na powierzchni kory, wewnattrz czaszki (elektrokortykogram, ECoG). Metoda ta charakteryzuje się bardzo dobrą rozdzielczościa czasowa i umożliwia badanie aktywności mózgu w stanie spoczynku i podczas rozwiazywania zadań poznawczych.

Wielu badaczy wskazuje, że synchroniczna aktywność sieci neuronalnych i oscylacji u ludzi oraz zwierząt ma szereg podobieństw (BUZSÁKI i DRAGUHN 2004, HAJÓs 2006), co stwarza możliwość porównania mechanizmów działania receptorów $\mathrm{CB} 1$ na aktywność elektryczna mózgu w obu grupach. Przeprowadzono wiele badań laboratoryjnych na zwierzętach, które sprawdzały wpływ THC i innych agonistów receptorów CB1 na aktywność elektryczną mózgu.
Receptory CB1 w korze mózgowej i hipokampie odgrywaja kluczowa rolę w koordynacji aktywności i uwalnianiu GABA (FARKAS i współaut. 2010), a przez to, w utrzymaniu równowagi pobudzenia i hamowania $w$ sieciach neuronalnych odpowiadających za procesy czuciowe, percepcyjne i poznawcze. Pobudzenie receptorów CB1 zmniejsza synchroniczność neuronów piramidalnych w hipokampie i redukuje hipokampalne i korowe oscylacje w paśmie theta i gamma (RoBBE i współaut. 2006, RoBBE i BuZSÁKI 2009, GOONAWARDENA i współaut. 2011, KUCEWICZ i współaut. 2011). Zaburzenia synchronizacji sieci spowodowane kannabinoidami moga stanowić podstawę upośledzonego przekazywania informacji przez zespoły neuronów $z$ hipokampa do kory nowej, a na poziomie behawioralnym, podawanie kannabinoidów powoduje deficyty w zadaniach wymagajacych zaangażowania hipokampa (RoBBE i BUZSÁKI 2009). 
$Z$ badań elektrofizjologicznych in vivo wiemy również, że agoniści receptora CB1 zaburzaja neuronalna sieć oscylacyjna w paradygmacie bramkowania zmysłowego (ang. sensory gating paradigm). Paradygmat bramkowania zmysłowego jest mechanizmem umożliwiającym wczesna formę uwagi filtrującej bodźce nieistotne spośród wszystkich bodźców środowiskowych. Efekt ten jest specyficzny dla receptorów CB1, ponieważ ulega całkowitemu odwróceniu przez podanie antagonisty receptorów CB1 (DISSANAYAKE i współaut. 2008, HAJÓs i współaut. 2008).

Agoniści receptora $\mathrm{CB} 1$ działaja na wzorzec aktywności elektrycznej mózgu w różny sposób, w zależności od lokalizacji receptorów. Receptory CB1, umiejscowione na neuronach GABAergicznych łączących prążkowie $z$ istota czarna, sa odpowiedzialne za hipersynchronizację pettli wzgórzowo-korowej, natomiast na korowych neuronach glutaminergicznych zmniejszaja synchronizację i amplitude szybkich oscylacji (SALES-CARBONELL i współaut. 2013). Sugeruje się, że hipersynchronicznośćc $c^{2}$ korowo-wzgórzowa może być mechanizmem leżącym u podłoża psychoaktywnego działania marihuany powodujacego „haj” oraz wzmożona wrażliwość na bodźce zmysłowe (SALES-CARBONELL i współaut. 2013). U naczelnych, receptory CB1 w korze mózgowej sa zlokalizowane głównie na interneuronach GABAergicznych, stad odpowiedź sieci neuronalnej na agonistów receptorów CB1 kształtuja najprawdopodobniej złożone interakcje między przekaźnictwem GABAergicznym a glutaminergicznym (EGGAN $\mathrm{i}$ LEWIS 2007).

Badania przeprowadzone na zwierzętach pokazuja jak istotna rolę odgrywa wiek, w którym nastapiła ekspozycja na kannabinoidy. U szczurów, którym w okresie dojrzewania podawano przez dłuższy czas agonistów receptora $\mathrm{CB} 1$, zaobserwowano thumienie farmakologicznie indukowanych oscylacji korowych i upośledzenie pamięci roboczej utrzymujące sie jeszcze $\mathrm{w}$ dorosłości (RAVER i współaut. 2013). Rejestracja lokalnych potencjałów polowych wykazała słabsze niż u zwierzat kontrolnych oscylacje w pasmach theta, alfa, beta i gamma, natomiast pomiar ECoG, w pasmach alfa i gamma. Efekt ten nie wystapił, kiedy ekspozycję na kannabinoidy zastosowano w okresie dorosłości. Mniejszą amplitudę potencjałów polowych rejestrowano przede wszystkim w obszarach czołowych kory, które nie były dojrzałe w trakcie ekspozycji na kannabinoidy (RAVER i współaut. 2013, RAVER i KELLER 2014). Kolejne badania pokazały, że potencjalnym me-

${ }^{2}$ regularna, wysoko zsynchronizowana aktywność neuronów (SALES-CARBONELL i współaut. 2013). chanizmem leżącym u podłoża tych zmian w oscylacjach moga być zaburzenia funkcjonowania neuronów GABAergicznych. U myszy, którym w okresie dojrzewania podawano agonistę receptorów $\mathrm{CB} 1$, zaobserwowano zaburzenia $\mathrm{w}$ dojrzewaniu funkcji $\mathrm{w}$ obrębie populacji neuronów GABAergicznych kory przedczołowej. Kiedy myszy były poddane ekspozycji na THC w dorosłości, takiego działania nie zaobserwowano (CASS i współaut. 2014).

Niewiele badań eksperymentalnych dotyczacych zmian $\mathrm{w}$ obrębie działania okolic czołowych po podaniu zwiąków THC przeprowadzono na ludziach, ale ich wyniki sa interesujące. LUKAS i współaut. (1995) poszukiwali psychofizjologicznych korelatów euforii wywołanej przez marihuanę. Osobom badanym podawano skręta $z$ marihuaną ( $z$ różna zawartościa THC) i rejestrowano aktywność elektryczna ich mózgu. Badani zgłaszali liczne pozytywne emocje i euforię wywołana zażyciem marihuany przez pierwsze 15 minut po wypaleniu skręta. Epizodom euforii towarzyszył wzrost poziomu THC w osoczu oraz wzrost mocy oscylacji w paśmie alfa i spadek mocy w paśmie beta, co autorzy interpretuja jako wyraz indukowanego przez THC stanu relaksu i zachodzacych procesów wzmocnienia.

Kolejne badania eksperymentalne dotyczyły wpływu marihuany na pamięć oraz zaburzeń aktywności elektrycznej mózgu będacych jego podłożem. IlAN i współaut. (2004, 2005) przeprowadzili serię badań na grupie okazjonalnych użytkowników marihuany. W pierwszym $z$ nich, osoby badane po zażyciu THC (lub placebo) wykonywały zadania mierzące pamięć roboczą i epizodyczną (Ilan i współaut. 2004). Pomiar EEG odbywał się w stanie spoczynkowym i w trakcie wykonywania zadań poznawczych. Na poziomie behawioralnym, w zadaniu mierzacym pamięć roboczą, u osób badanych zażywających THC stwierdzono dłuższy czas reakcji oraz spadek dokładności, jednak tylko w przypadku, gdy obciażenie pamięci roboczej było duże. Po ekspozycji na THC zaobserwowano również spadek zdolności rozróżniania pomiędzy starymi a nowymi bodźcami; nowe bodźce były częściej rozpoznawane jako wcześniej eksponowane. $\mathrm{Na}$ poziomie psychofizjologicznym po zażyciu marihuany wystapił spadek mocy $\mathrm{w}$ paśmie beta $\mathrm{i}$ theta na powierzchni całej czaszki, we wszystkich warunkach pomiaru EEG. Palenie marihuany zaburzało również aktywność w paśmie alfa; była ona mniejsza $\mathrm{w}$ porównaniu do warunku placebo, niezależnie od poziomu trudności zadania. Spadek mocy $\mathrm{w}$ paśmie alfa (desynchronizacja) traktuje się jako psychofizjologiczna manifestacje aktywności korowej (PFURTSCHELLER 
i współaut. 1996) i jest uważany za miarę ilości wysiłku wkładanego w wykonanie zadania. Największy spadek mocy występował u osób, które subiektywnie oceniały swój stan jako najbardziej odurzony. Zdaniem autorów, wynik badania świadczy o tymczasowym, farmakologicznym zakłóceniu przez THC mechanizmów pamięciowych w płatach czołowych i w przyśrodkowej części płata skroniowego, które sa kluczowe dla funkcjonowania uwagi długotrwałej oraz pamięci roboczej i epizodycznej. Po zażyciu marihuany, w stanie „haju”, trudno utrzymać spójny ciąg myśli ze względu na stała intruzję niezwiazanych informacji. Przyczyna tej reakcji może być aktywacja receptorów $\mathrm{CB} 1$, zaburzajaca selektywne filtrowanie informacji na istotne i takie, które powinny być odrzucone (POLLAN 2001).

Kolejne badanie ILANA i współaut. (2005) miało na celu sprawdzenie, czy inne kannabinoidy zawarte $\mathrm{w}$ marihuanie, kannabichromen (ang. cannabichromene, CBC) i CBD, moga modyfikować wpływ samego THC (ENGLUND i współaut. 2013). Badacze przygotowali dla osób badanych skręty zawierajace cztery różne kombinacje stężeń powyższych kannabinoidów oraz placebo. Procedura badawcza była analogiczna do wykorzystanej w przednim badaniu. Na poziomie behawioralnym zaobserwowano spadek dokładności i większy czas reakcji w zadaniu mierzacym pamięć robocza, we wszystkich warunkach poza placebo. Jednocześnie, po zażyciu marihuany wystapił spadek mocy w pasmie theta, rejestrowany $z$ elektrod na całej czaszce, oraz zmniejszenie mocy w pasmach alfa i beta w obszarach przednich i centralnych, zarówno w stanie spoczynku, jak i podczas wykonywania zadań. Nie zaobserwowano, by zawartość innych kannabinoidów ograniczała wpływ THC na aktywność EEG, jednak zdaniem badaczy może to wynikać $z$ małych dawek wykorzystanych w badaniu były one znacznie mniejsze niż w naturalnie występujacej marihuanie.

Ostatnie badanie wykorzystujace wspomniana procedurę w grupie użytkowników marihuany przeprowadzone przez ten zespół badawczy (HART i współaut. 2010) miało na celu sprawdzenie, czy zaobserwowane w grupie okazjonalnych użytkowników efekty pojawią się również w grupie użytkowników regularnych. W tym eksperymencie regularnym użytkownikom marihuany podawano skręty $z$ różna zawartościa THC (w tym placebo). Okazało się, że marihuana ma znikomy wpływ na pamięć epizodyczna i robocza u regularnych palaczy. Palenie nie wpływało na dokładność w żadnym $z$ zadań poznawczych, ale wydłużało czas ich wykonania. Po paleniu marihuany zaobserwowano, podob- nie jak w przednim badaniu, spadek mocy w paśmie theta i beta, zarówno podczas rozwiazywania zadań poznawczych, jak i w stanie spoczynku.

BÖCKER i współaut. (2010) chcieli sprawdzić, czy opisana wcześniej modulacja pasma theta jest spowodowana wyłacznie zażyciem THC, czy też większe znaczenie ma wpływ wykonywanych zadań (szczególnie pamięciowych). Autorzy badania podawali regularnym użytkownikom marihuany skręty zawierajace THC w czterech różnych stężeniach $(0,0 ; 29,3 ; 49,1$ i $69,4 \mathrm{mg})$, po czym osoby badane wykonywały zadania mierzace sprawność pamięci krótkotrwałej i uwagi. Rejestracja aktywności EEG odbywała się w stanie spoczynku, w przerwie pomiędzy zadaniami. Na poziomie behawioralnym zaobserwowano, że wraz ze wzrostem stężenia THC istotnie zwiększał się czas reakcji $\mathrm{i}$ liczba błędów w obu zadaniach. Istotny efekt dawki wystapił również dla aktywności oscylacyjnej - spadek mocy w paśmie theta oraz wzrost mocy w paśmie beta. Autorzy próbowali wyjaśnić uzyskane wyniki odwołując się do sieci stanu spoczynkowego (ang. default mode network, DMN). Sieć DMN to jedna $z$ podstawowych sieci funkcjonalnych, która łączy regiony mózgu aktywujące się przede wszystkim w sytuacji spoczynkowej. Sieć ta znacznie zmniejsza swoją aktywność podczas wykonywania zadań poznawczych (RAICHLE 2010). Aktywność sieci DMN jest zwiąana $z$ występowaniem marzeń na jawie czy koncentracja na własnych stanach psychicznych. Badania pokazuja, że zwiększenie mocy $w$ paśmie theta wiąże się ze spadkiem aktywności DMN i odwrotnie, spadek mocy w paśmie theta towarzyszy wzrostowi aktywności tej sieci (SCHEERINGA i współaut. 2008). Odpowiada to sytuacji, gdy zmniejszenie mocy pasma theta po podaniu THC wiąze się ze zwiększeniem aktywności sieci DMN. Potwierdza to także wzrost mocy w paśmie beta, ponieważ doniesienia $z$ innych badań pokazuja, że aktywność sieci DMN koreluje także ze wzrostem mocy w paśmie beta (LAUFs i współaut. 2003). Rzeczywiście niektóre objawy intoksykacji spowodowanej podaniem THC sa typowe dla aktywności sieci DMN.

SKosNiK i współaut. (2014) chcieli przekonać się, czy kannabinoidy zaburzaja aktywność oscylacyjna $\mathrm{w}$ paśmie gamma u ludzi oraz czy jest ona zwiazana $z$ wysteppowaniem objawów psychotycznych po zażyciu marihuany. Naukowcy sprawdzali wpływ różnych poziomów stężenia THC (placebo, 0,015 i $0,03 \mathrm{mg} / \mathrm{kg}$ ) na słuchowe potencjały wywołane stanu ustalonego (ang. auditory steady-state responses, ASSR). ASSR to elektrofizjologiczna odpowiedź narządu słuchu na 
serię powtarzanych bodźców dźwiękowych. Pomiar aktywności EEG odbywał się podczas stymulacji specyficznej częstotliwościowo (20, 30 i $40 \mathrm{~Hz}$ ). Po obliczeniu koherencji między próbami (ang. inter-trial coherence, ITC), która jest miara spójności faz oscylacyjnych $\mathrm{w}$ reakcji mózgu na bodziec $\mathrm{w}$ kolejnych próbach, okazało się, że podanie THC prowadzi do zmniejszenia ITC, co jest równoznaczne ze wzrostem wewnatrzosobniczej zmienności w odpowiedzi mózgu na identyczne bodźce. Ta, indukowana przez THC, zmienność może odzwierciedlać większy udział szumu $\mathrm{w}$ procesach neuronalnych leżących u podstaw ASSR. Podobne zjawisko obserwuje się w schizofrenii, co może świadczyć o zbliżonym mechanizmie generowania stanów psychotycznych w obu przypadkach. Co więcej, CORTES-BRIONES i współaut. (2015) wykazali, że podanie THC generuje u osób badanych nadaktywność korowa (ang. noisy brain) w okresie przed pojawieniem się bodźca. Ta nadaktywność korelowała $z$ występowaniem psychotycznych efektów działania THC w sposób liniowy, w zależności od przyjętej dawki. Z przeprowadzonych dotychczas badań wiemy również, że wzorzec aktywności EEG jest zaburzony u osób długotrwale zażywających marihuanę. Były to przede wszystkim badania rejestrujące aktywność mózgu w stanie spoczynkowym, kiedy osoba uczestniczaca nie jest zaangażowana w aktywność poznawczą. Co ważne, nie jest to zupełna bierność, ale raczej stan reaktywności/gotowości na zmieniające się bodźce środowiskowe - powiazany $z$ funkcjonowaniem poznawczym. Poprzednie badania wykazały, że aktywność neuronalna $\mathrm{w}$ stanie spoczynkowym jest zaburzona u osób zażywających substancje psychoaktywne, co odzwierciedlaja zmiany w widmie mocy sygnału EEG, szczególnie w paśmie delta. Oscylacje delta sa powiazane $z$ procesami motywacyjnymi i nagroda (Tabela 1). Częstotliwości delta generowane sa $\mathrm{w}$ obszarach podkorowych, jadrze półleżącym, polu brzusznym nakrywki oraz części przyśrodkowej kory przedczołowej i odgrywaja ważna rolę $\mathrm{w}$ komunikacji między tymi obszarami (GRUBER i współaut. 2009, FUJISAWA i BUZSÁKI 2011). Badając osoby uzależnione od marihuany EHLERS i współaut. (2010) zaobserwowali dodatnia korelację pomiędzy moca $\mathrm{w}$ paśmie delta, rejestrowana $\mathrm{w}$ stanie spoczynkowym, a zależnościa od marihuany. LAPREVOTE i współaut. (2017) również chcieli sprawdzić jaka rolę odgrywa zespół uzależnienia od marihuany w aktywności elektrycznej mózgu. W tym celu zbadali trzy grupy: kontrolna, użytkowników marihuany niespełniajacych kryterium uzależnienia oraz użytkowników spełniajacych to kryterium. Badacze ci wykazali, że uzależnienie od marihuany jest zwiazane ze zwiększona spontaniczna złożonościa Lempela-Ziva ${ }^{3}$ aktywności elektrycznej mózgu, co potwierdza wyniki badań na użytkownikach pod bezpośrednim wpływem marihuany (CORTES-BRIONES i współaut. 2015). Odzwierciedla to zwiększony udział szumu w aktywności neuronalnej u osób uzależnionych od marihuany.

Badania prowadzone przez zespół badawczy pod kierownictwem Struve'a (STRUVE i współaut. 1994, 1998, 1999) wykazały zwiększona moc oscylacji w pasmach alfa $i$ theta oraz obniżona $\mathrm{w}$ pasmach delta i beta $\mathrm{u}$ długotrwałych użytkowników marihuany. Jednak w kolejnych badaniach regularnych użytkowników zaobserwowano odmienny wzorzec aktywności spoczynkowego EEG po okresie abstynencji, w stosunku do takiego wzorca $z$ poprzednich badań. Wystapiła u nich istotnie obniżona moc oscylacji na całej czaszce $\mathrm{w}$ pasmach theta $\mathrm{i}$ alfa $1(8-10 \mathrm{~Hz})$ oraz niższa moc oscylacji w pasmach alfa 2 $(10-13 \mathrm{~Hz})$ i beta $2(25-40 \mathrm{~Hz})$ w obszarach potylicznych, w porównaniu $z$ grupa kontrolną (HERNING i współaut. 2003, 2008). Jedno $z$ najnowszych badań wykazało obniżona moc oscylacji w paśmie delta i zwiększona moc $w$ pasmach theta, beta i gamma $u$ użytkowników marihuany, w porównaniu do grupy kontrolnej. Taki wzorzec aktywności EEG sugeruje zwiększona aktywność kory w stanie spoczynku oraz rozhamowanie/zaburzenia funkcji hamowania, które moga zmieniać procesy poznawcze (PRASHAD i współaut. 2018). Tabela 2 przedstawia podsumowanie opisanych badań.

Przedstawione wyniki badań dowodzą, że marihuana zaburza aktywność elektryczną mózgu u ludzi, zarówno kiedy sa pod jej bezpośrednim wplywem (badania eksperymentalne), jak i przy długotrwałym zażywaniu (badania korelacyjne). Natomiast badania na zwierzętach pozwalaja lepiej zrozumieć mechanizmy wyjaśniajace wpływ marihuany na oscylacje neuronalne. Stwierdzono w nich, że THC tłumi aktywność oscylacji theta przez zaburzenie synchronicznej aktywności zespołów komórek nerwowych w hipokampie (SOLTESz i współaut. 2015), co może przyczyniać się do obserwowanych dysfunkcji pamięci roboczej i epizodycznej. W warunkach kontrolnych hipokamp generuje synchroniczną aktywność zespołów neuronów. Zespoły neuronów generuja skoordynowane potencjały czynnościowe podczas cykli theta. THC tłumi oscylacje theta

${ }^{3}$ złożoność Lempela-Ziv'a (ang. Lempel-Ziv Complexity, LZC) - nieparametryczna metoda analizy złożoności sygnału, obliczana na podstawie ilości niezależnych ciąów znaków i częstości ich ponownego wystapienia w danej sekwencji (LAPREVOTE i współaut. 2017). 
Tabela 2. Przegląd badań dotyczacych wpływu marihuany na aktywność EEG.

\begin{tabular}{|c|c|c|}
\hline Rodzaj badania & pasma & Zmiany aktywności EEG \\
\hline $\begin{array}{l}\text { badania eksperymen- } \\
\text { talne na zwierzętach }\end{array}$ & $\begin{array}{l}\text { theta, alfa, beta } i \\
\text { gamma }\end{array}$ & $\begin{array}{l}\text { - podawanie szczurom przez dłuższy czas agonistów receptora CB1 } \\
\text { prowadziło do tłumienia farmakologicznie indukowanych oscylacji } \\
\text { korowych i upośledzenie pamięci roboczej utrzymujące się jeszcze w } \\
\text { dorosłości. Rejestracja lokalnych potencjałów polowych u tych zwie- } \\
\text { rzat wykazała słabsze oscylacje w pasmach theta, alfa, beta i gam- } \\
\text { ma, natomiast pomiar z użyciem elektrokortykogramu, w pasmach } \\
\text { alfa i gamma. Efekt ten nie wystapił, kiedy ekspozycja na kanna- } \\
\text { binoidy następowała w okresie dorosłości (RAVER i współaut. 2013, } \\
\text { RAVER i KELLER 2014, CASS i współaut. 2014); }\end{array}$ \\
\hline
\end{tabular}

theta i gamma - pobudzenie receptorów CB1 przez agoniste powodowało redukcję hipokampalnych i korowych oscylacji w paśmie theta i gamma, co wiazało się $z$ nasilonymi deficytami w zadaniach wymagajacych zaangażowania hipokampa (RoBBE i współaut. 2006, RoBBE i BUZSÁKI 2009, GoonaWARDEna i współaut. 2011, KUCEWicz i współaut. 2011)

- agoniści receptora CB1 zaburzaja neuronalna sieć oscylacyjna (redukuja amplitudę oscylacji $\mathrm{w}$ paśmie theta i gamma $\mathrm{w}$ hipokampie i korze śródwęchowej) w paradygmacie bramkowania zmysłowego zwiazanym z wczesną formą uwagi (DisSANAYAKE i współaut. 2008, HAJÓs i współaut. 2008)

sieć oscylacyjna w - agoniści receptora CB1 powoduja hipersynchronizację oscylacji zakresie częstotliwo- wzgórzowo-korowych oraz zmniejszają synchronizację i amplitudę ści 4-6 Hz szybkich oscylacji w korze czuciowej (SALES-CARBonell i współaut. 2013)

badania eksperymen- alfa i beta - wzrost mocy oscylacji w paśmie alfa i spadek mocy w paśmie beta talne na ludziach towarzyszył epizodom euforii po zażyciu marihuany i wiazał się ze wzrostem poziomu THC w osoczu (LUKAs i współaut. 1995)

beta, alfa i theta - po zażyciu marihuany u osób badanych wystapił spadek mocy w paśmie beta i alfa oraz w paśmie theta na powierzchni całej czaszki podczas wykonywania zadań poznawczych oraz w stanie spoczynku. Na poziomie behawioralnym, w zadaniu mierzącym pamięć robocza u osób badanych zażywających THC stwierdzono dłuższy czas reakcji oraz spadek dokładności (ILAN i współaut. 2004)

- po zażyciu marihuany u osób badanych wystapił spadek mocy w paśmie theta $\mathrm{w}$ odprowadzeniach $\mathrm{z}$ całej czaszki oraz zmniejszenie mocy $\mathrm{w}$ pasmach alfa $\mathrm{i}$ beta $\mathrm{w}$ obszarach przednich i centralnych $\mathrm{w}$ stanie spoczynku oraz podczas wykonywania zadań. Na poziomie behawioralnym zaobserwowano spadek dokładności oraz dłuższy czas reakcji w zadaniu mierzącym pamięć roboczą (ILAN i współaut. 2005)

theta i beta - po podaniu marihuany regularnym użytkownikom zaobserwowano spadek mocy $\mathrm{w}$ paśmie theta i beta podczas rozwiąywania zadań poznawczych oraz w stanie spoczynku; nie zaobserwowano wpływu na dokładność odpowiedzi w żadnym z zadań poznawczych, ale zwiększał się czas ich wykonania (HART i współaut. 2010)

- po podaniu THC zaobserwowano zmiany aktywności oscylacyjnej rejestrowanej $\mathrm{w}$ stanie spoczynku - spadek mocy $\mathrm{w}$ paśmie theta oraz wzrost mocy w paśmie beta, efekt był zależny od dawki. Na poziomie behawioralnym zaobserwowano, że wraz $z$ wzrostem stężenia THC istotnie zwiększał się czas reakcji i liczba błędów w obu zadaniach (BÖcKER i współaut. 2010) 


\begin{tabular}{|c|c|c|}
\hline & \multirow[b]{2}{*}{ gamma } & \multirow[b]{2}{*}{$\begin{array}{l}\text { - kannabinoidy zaburzaja aktywność oscylacyjna w paśmie gamma } \\
\text { także u ludzi - THC prowadzi do zmniejszenia ITC, co jest równo- } \\
\text { znaczne ze wzrostem wewnatrzosobniczej zmienności w odpowiedzi } \\
\text { mózgu na identyczne bodźce (SKosNik i współaut. 2014) }\end{array}$} \\
\hline & & \\
\hline & $\begin{array}{l}\text { nadaktywność } \\
\text { korowa }\end{array}$ & $\begin{array}{l}\text { - podanie THC generuje u osób badanych nadaktywność korowa } \\
\text { (ang. noisy brain) w okresie przed pojawieniem się bodźca (CORTES- } \\
\text {-BRIONEs i współaut. 2015) }\end{array}$ \\
\hline & & $\begin{array}{l}\text { - uzależnienie od marihuany jest związane ze zwiększona sponta- } \\
\text { niczną złożonością aktywności elektrycznej mózgu (LAPREVote i } \\
\text { współaut. 2017) }\end{array}$ \\
\hline \multirow[t]{4}{*}{$\begin{array}{l}\text { badania korelacyjne } \\
\text { na ludziach }\end{array}$} & delta & $\begin{array}{l}\text { - występuje pozytywna korelacja pomiędzy moca w paśmie delta re- } \\
\text { jestrowana w stanie spoczynku, a zależnościa od marihuany (EHLERS } \\
\text { i współaut. 2010) }\end{array}$ \\
\hline & $\begin{array}{l}\text { alfa, theta, delta, } \\
\text { beta }\end{array}$ & $\begin{array}{l}\text { - zwiększona moc oscylacji w pasmach alfa i theta oraz obniżona } \\
\text { w pasmach delta i beta u długotrwałych użytkowników marihuany } \\
\text { (STRUVE i współaut. 1994, 1998, 1999) }\end{array}$ \\
\hline & & $\begin{array}{l}\text { - obniżona moc oscylacji w paśmie delta i zwiększona moc w pa- } \\
\text { smach theta, beta i gamma u użytkowników marihuany w porówna- } \\
\text { niu do grupy kontrolnej (sugeruje to zwiększona synchronizacje kory } \\
\text { w stanie spoczynku) (PRASHAD i współaut. 2018) }\end{array}$ \\
\hline & theta, alfa, beta & $\begin{array}{l}\text { - istotnie obniżona moc oscylacji w odprowadzeniach } z \text { całej czasz- } \\
\text { ki w pasmach theta i alfa } 1(8-10 \mathrm{~Hz}) \text { oraz niższa moc oscylacji w } \\
\text { pasmach alfa } 2(10-13 \mathrm{~Hz}) \text { i beta } 2(25-40 \mathrm{~Hz}) \text { w obszarach poty- } \\
\text { licznych u długotrwałych użytkowników marihuany po okresie absty- } \\
\text { nencji (HERNING i współaut. 2003, 2008) }\end{array}$ \\
\hline
\end{tabular}

i zaburza koordynację czasowa aktywności zespołów neuronów (SOLTESz i współaut. 2015). Najprawdopodobniej zaangażowane w ten proces sa zarówno neurony GABAergiczne, jak i glutaminergiczne. Natomiast aktywacja receptorów $\mathrm{CB} 1$, znajdujących się na neuronach GABAergicznych łaczacych prążkowie $\mathrm{z}$ istotą czarna, zwiększa synchronizację pętli wzgórzowo-korowej, co sugeruje, że zmniejszenie uwalniania neuroprzekaźników spowodowane aktywnościa receptorów CB1 może również ułatwiać działanie niektórych sieci oscylacyjnych (SALES-CARBONELL i współaut. 2013).

W badaniach korelacyjnych obserwuje się większą rozbieżność uzyskanych wyników, która utrudnia wyciagnięcie jednoznacznych wniosków dotyczacych długotrwałych efektów zażywania marihuany. Przyczyn takich rozbieżności można upatrywać przede wszystkim w różnych wzorcach zażywania marihuany (okazjonalni vs regularni użytkownicy us osoby uzależnione od marihuany) oraz innych substancji psychoaktywnych, w tym tytoniu i alkoholu. Zazwyczaj zmienne te sa słabo kontrolowane, ponieważ w badaniach najczęściej wykorzystywano miary deklaratywne zamiast obiektywnych (np. analizy biochemicznej próbek włosów pod katem substancji psychoaktywnych). O istotnej roli jednoczesnego zażywania innych substancji psychoaktywnych świadczą choćby badania $\mathrm{w}$ grupie osób będących regularnymi użytkownikami marihuany i tytoniu. Badania pokazuja, że łączne zażywanie obu substancji może nasilać zaburzenia połaczeń tylnych obszarów kory i obszarów czołowo-ciemieniowych (JACOBSEN i współaut. 2007) oraz prowadzić do nieoczywistych zmian w aktywności sieci DMN (FILBEY i współaut. 2018). W grupie zażywającej obie substancje stwierdzono wzorzec aktywności sieci DMN bardziej zbliżony do grupy kontrolnej niż grupy zażywajacej jedynie nikotynę lub marihuanę (jednakowo obniżona łączność funkcjonalna). Jak więc wynika $z$ naszego przegladu, potrzeba jeszcze wielu badań, abyśmy mogli lepiej zrozumieć wpływ marihuany na aktywność elektryczną mózgu człowieka, szczególnie przy jej długotrwałym używaniu.

\section{Streszczenie}

Marihuana jest obecnie jedna $z$ najpopularniejszych i najczęściej zażywanych substancji psychoaktywnych na świecie. Konopie indyjskie, $z$ których produkuje się marihuanę, zawieraja ponad 140 różnych zwiąków aktywnych - kannabinoidów. Najbardziej znane kanabinoidy to tetrahydrokannabinol (THC) i kannabidiol (CBD). Kannabinoidy działaja na układ endokannabinoidowy odgrywający istotna rolę $\mathrm{w}$ utrzymaniu homeostazy organizmu oraz $\mathrm{w}$ procesach neuroplastyczności. Celem artykułu jest przybliżenie czytelnikowi wiedzy na temat wpływu marihuany na procesy biochemiczne oraz ak- 
tywność elektryczną mózgu u zwierząt i ludzi. Przedstawione badania pokazuja, że marihuana zaburza aktywność elektryczna mózgu u ludzi, zarówno kiedy sa pod jej bezpośrednim wpływem, jak i przy długotrwałym zażywaniu. Natomiast badania na zwierzętach pozwalaja nam lepiej zrozumieć mechanizmy, przez które marihuana zmienia oscylacje neuronalne.

\section{LITERATURA}

ABOod M. E., MARTin B. R., 1996. Molecular neurobiology of the cannabinoid receptor. Int. Rev. Neurobiol. 39, 197-221.

ABUSH H., AKIRAV I., 2010. Cannabinoids modulate hippocampal memory and plasticity. Hippocampus 20, 1126-1138.

Alger B. E., KIM J., 2011. Supply and demand for endocannabinoids. Trends Neurosci. 34, 304-315.

AMERI A., 1999. The effects of cannabinoids on the brain. Prog. Neurobiol. 58, 315-348.

AXELROD J., FELDER C. C., 1998. Cannabinoid receptors and their endogenous agonist, anandamide. Neurochem. Res. 23, 575-581.

BAŞAR E., BAŞAR-EROĞLU C., KARAKAŞ S., SCHÜRMANN M., 1999. Are cognitive processes manifested in event-related gamma, alpha, theta and delta oscillations in the EEG? Neurosci. Lett. 259, 165-168.

BAŞAR E., ÖZGÖREN M., KARAKAŞ S., BAŞAREROĞLU C., 2004. Super-synergy in the brain: The grandmother percept is manifested by multiple oscillations. Int. J. Bifurc. Chaos 14, 453-491.

BEFORT K.. 2015. Interactions of the opioid and cannabinoid systems in reward: Insights from knockout studies. Front. Pharmacol. 6, 6.

BhatTacharya J., PETsche H., 2002. Shadows of artistry: Cortical synchrony during perception and imagery of visual art. Cognit. Brain Res. 13, 179-186.

Bland B., 1986. The physiology and pharmacology of hippocampal formation theta rhythms. Prog. Neurobiol. 26, 1-54.

Bland B., COLOM L., 1993. Extrinsic and intrinsic properties underlying oscillation and synchrony in limbic cortex. Prog. Neurobiol. 41, 157208.

Böcker K. B., Hunault C. C., Gerritsen J., KruIDENiER M., MEnsinga T. T., Kenemans J. L. 2010. Cannabinoid modulations of resting state EEG theta power and working memory are correlated in humans. J. Cognit. Neurosci. 22, 1906-1916.

Bragin A., JANDó G., NADAsdy Z., HetKe J., Wise K., BuZsÁKI G., 1995. Gamma (40-100 Hz) oscillation in the hippocampus of the behaving rat. J. Neurosci. 15, 47-60.

BuZsÁKI G., DRAGUHN A., 2004. Neuronal oscillations in cortical networks. Science 304, 19261929.

CABERlotTo L., Rimondini R., HANSSON A., ERIKSSON S., HEILIG M., 2004. Corticotropin-releasing hormone (CRH) mRNA expression in rat central amygdala in cannabinoid tolerance and withdrawal: evidence for an allostatic shift?. Neuropsychopharmacology 29, 15.

Calabrese E. J., RUBIO-CASIllas A., 2018. Biphasic effects of THC in memory and cognition. Eur. J. Clin. Invest. 48, e12920.

CAMPOS A., GuIMARÃES F., 2008. Involvement of $5 H T 1 A$ receptors in the anxiolytic-like effects of cannabidiol injected into the dorsolateral periaqueductal gray of rats. Psychopharmacology $199,223$.
CAss D. K., Flores-Barrera E., Thomases D. R., Vital W. F., Caballero A., TSEnG K. Y., 2014. CB1 cannabinoid receptor stimulation during adolescence impairs the maturation of $G A B A$ function in the adult rat prefrontal cortex. Mol. Psychiatry 19, 536.

ChAN G. C. K., Hinds T. R., IMPEY S., STORM D. R., 1998. Hippocampal neurotoxicity of $\Delta 9$ tetrahydrocannabinol. J. Neurosci. 18, 53225332

Cheer J. F., Wassum K. M., Heien M. L., PhilLIPS P. E., WightMan R. M., 2004. Cannabinoids enhance subsecond dopamine release in the nucleus accumbens of awake rats. J. Neurosci. 24, 4393-4400.

Chen J., Marmur R., Pulles A., Paredes W., GARDNER E. L., 1993. Ventral tegmental microinjection of $\Delta 9$-tetrahydrocannabinol enhances ventral tegmental somatodendritic dopamine levels but not forebrain dopamine levels: evidence for local neural action by marijuana's psychoactive ingredient. Brain Res. 621, 6570 .

Cortes-Briones J. A., CAHILl J. D., Skosnik,P. D., Mathalon D. H., Williams A., Sewell R. A., D'souzA D. C., 2015. The psychosis-like effects of $\Delta$ 9-tetrahydrocannabinol are associated with increased cortical noise in healthy humans. Biol. Psychiatry 78, 805-813.

CuRRan H. V., FreEMan T. P., MOKRYsz C., LEWIS D. A., Morgan C. J., PARsons L. H., 2016. Keep off the grass? Cannabis, cognition and addiction. Nat. Rev. Neurosci. 17, 293.

DE FONSECA F. R., CARRERA M. R. A., NAVARRO M., KоOB G. F., WeISS F., 1997. Activation of corticotropin-releasing factor in the limbic system during cannabinoid withdrawal. Science 276, 2050-2054.

DE GENNARO L., FERRARA M., BERTINI M., 2000. The spontaneous $K$-complex during stage 2 sleep: Is it the 'forerunner' of delta waves? Neurosci. Lett. 291, 41-43.

DegenhardT L., ChIU W. T., SAmpson N., Kessler R. C., ANTHONY J. C., ANGERMEYer M., KARAM A., 2008. Toward a global view of alcohol, tobacco, cannabis, and cocaine use: findings from the WHO World Mental Health Surveys. PLoS Med. 5, e141.

Demirakca T., SARTORius A., Ende G., Meyer N., Welzel H., SKopp G., HeRMANN D., 2011. Diminished gray matter in the hippocampus of cannabis users: possible protective effects of cannabidiol. Drug Alcohol Depend. 114, 242245.

DisSANAYAKE D. W., ZACHARIOU M., MARSDEN C. A., MASON R., 2008. Auditory gating in rat hippocampus and medial prefrontal cortex: effect of the cannabinoid agonist WIN55, 212-2. Neuropharmacology 55, 1397-1404.

DOWNER E., BOLAND B., FOGARTY M., CAMPBELL V., 2001. 49 -Tetrahydrocannabinol induces the apoptotic pathway in cultured cortical neurones via activation of the $C B 1$ receptor. Neuroreport 12, 3973-3978.

Egerton A., Allison C., BREtT R. R., PRATT J. A., 2006. Cannabinoids and prefrontal cortical function: insights from preclinical studies. Neurosci. Biobehavi. Rev. 30, 680-695.

EGGAN S. M., LEWIS D. A., 2007. Immunocytochemical distribution of the cannabinoid CB1 receptor in the primate neocortex: a regional and laminar analysis. Cereb. Cortex 17, 175191.

Ehlers C., Phillips E., Gizer I., Gilder D., WilHELMSEN K., 2010. EEG spectral phenotypes: Heritability and association with marijuana 
and alcohol dependence in an American Indian community study. Drug Alcohol Depend. 106, 101-110.

Englund A., MORRISON P. D., NotTAge J., HAGUE D., Kane F., Bonaccorso S., FEILding A., 2013. Cannabidiol inhibits THC-elicited paranoid symptoms and hippocampal-dependent memory impairment. J. Psychopharmacol. 27, 19-27.

Farkas I., Kallo I., Deli L., Vida B., HrabovszKY E., FEKETE C., Liposits Z., 2010. Retrograde endocannabinoid signaling reduces GABAergic synaptic transmission to gonadotropin-releasing hormone neurons. Endocrinology 151, 5818-5829.

Fell J., Klaver P., Lehnertz K., Grunwald T., SCHAller C., Elger C., Fernandez G., 2001 Human memory formation is accompanied by rhinal-hippocampal coupling and decoupling. Nat. Neurosci. 4, 1159-1160.

Filbey F. M., Gohel S., PRAshad S., Biswal B. B., 2018. Differential associations of combined vs. isolated cannabis and nicotine on brain resting state networks. Brain Struct. Funct. 223, 3317-3326.

Fries P. REYNOLDS J., RoRIE A., DESIMONE R., 2001. Modulation of oscillatoryneuronal synchronization by selective visual attention Science 291, 1560-1563.

FUJISAWA S., BUZSÁKI G., 2011. A $4 \mathrm{~Hz}$ oscillation adaptively synchronizes prefrontal, VTA, and hippocampal activities. Neuron 72, 153-165.

GAONI Y., MECHOUlAM R., 1964. Isolation, structu re, and partial synthesis of an active constituent of hashish. J. Am. Chem. Soc. 86, 16461647.

Glass M., FAull R. L. M., DRAgunow M., 1993. Loss of cannabinoid receptors in the substantia nigra in Huntington's disease. Neuroscience 56, 523-527.

GifFORD A. N., SAMilan L., GATley S. J., Ashby JR C. R., 1997. Examination of the effect of the cannabinoid receptor agonist, CP 55,940, on electrically evoked transmitter release from rat brain slices. Eur. J. Pharmacol. 324, 187192.

GoonaWARdena A. V., Riedel G., HAMPSON R. E. 2011. Cannabinoids alter spontaneous firing, bursting, and cell synchrony of hippocampal principal cells. Hippocampus 21, 520-531.

GRAY C., 1994. Synchronous oscillations in neuronal systems (mechanisms and functions). J. Comput. Neurosci. 1, 11-38.

GRUBER A. J., HUSSAIN R. J., O'DONNELl P., 2009. The nucleus accumbens: a switchboard for goal-directed behaviors. PloS One 4, e5062.

HAJós M., 2006. Targeting information-processing deficit in schizophrenia: a novel approach to psychotherapeutic drug discovery. Trends Pharmacol. Sci. 27, 391-398.

HAJÓS M., HOFFMANN W. E., Kocsis B., 2008. Activation of cannabinoid-1 receptors disrupts sensory gating and neuronal oscillation: relevance to schizophrenia. Biol. Psychiatry 63, 1075-1083.

HANDEL B., HAARMEIER T., JENSEN O., 2011. Alpha oscillations correlate with the successful inhibition of unattended stimuli. J. Comput. Neurosci. 23, 2494-2502.

HanuŠ L. O., MEYer S. M., Muñoz E., TAglialaTELA-SCAFATI O., APPENDINO G., 2016. Phytocannabinoids: a unified critical inventory. Nat. Prod. Rep. 33, 1357-1392.

Hart C. L., Ilan A. B., Gevins A., Gunderson E. W., Role K., Colley J., Foltin R. W., 2010. Neurophysiological and cognitive effects of smoked marijuana in frequent users. Pharmacol. Biochem. Behav. 96, 333-341.

HEATH R. G., FITZJARRELl A. T., FONTANA C. J., GAREY R. E., 1980. Cannabis sativa: effects on brain function and ultrastructure in rhesus monkeys. Biol. Psychiatry 15, 657-690.

HERKENHAM M., LYNN A. B., LITTLE M. D., JOHNSON M. R., Melvin L. S., De Costa B. R., RICE K. C., 1990. Cannabinoid receptor localization in brain. Proc. Natl. Acad. Sci. USA 87, 1932-1936.

Herning R. I., BetTer W., TAte, K., CAdet J. L., 2003. EEG deficits in chronic marijuana abu sers during monitored abstinence. Ann. NY Acad. Sci. 993, 75-78.

HeRning R. I., BETTER W., CADET J. L., 2008. EEG of chronic marijuana users during abstinence: relationship to years of marijuana use, cerebral blood flow and thyroid function. Clin. Neurophysiol. 119, 321-331.

Higuera-Matas A., Botreau F., Del Olmo N., MiGuéns M., Olías Ó., Montoya G. L., AmBRoSIO E., 2010. Periadolescent exposure to cannabinoids alters the striatal and hippocampal dopaminergic system in the adult rat brain. Eur. Neuropsychopharmacol. 20, 895-906.

HiNDOCHA C., FREEMAN T. P., Winstock A. R., LYNSKEY M. T., 2016. Vaping cannabis (marijuana) has the potential to reduce tobacco smoking in cannabis users. Addiction 111, 375

Hoffman A. F., LuPICA C. R., 2001. Direct actions of cannabinoids on synaptic transmission in the nucleus accumbens: a comparison with opioids. J. Neurophysiol. 85, 72-83.

Huestis M. A., GORELICK D. A., HeISHMAN S. J., Preston K. L., Nelson R. A., MoOlchan E. T., FRANK R. A., 2001. Blockade of effects of smoked marijuana by the CB1-selective cannabinoid receptor antagonist SR141716. Arch. Gen. Psychiatry 58, 322-328.

Ilan A. B., SMith M. E., Gevins A., 2004. Effects of marijuana on neurophysiological signals of working and episodic memory. Psychopharmacology 176, 214-222.

Ilan A. B., Gevins A., Coleman M., Elsohly M. A., DE WIT H., 2005. Neurophysiological and subjective profile of marijuana with varying concentrations of cannabinoids. Behav. Pharmacol. 16, 487-496.

Jacobsen L. K., Pugh K. R., Constable R. T., Westerveld M., Mencl W. E., 2007. Functional correlates of verbal memory deficits emerging during nicotine withdrawal in abstinent adolescent cannabis users. Biol. Psychiatry 61, 31-40.

KATONA I., FREUND T. F., 2012. Multiple functions of endocannabinoid signaling in the brain. Ann. Rev. Neurosci. 35, 529-558.

KNYAZEV G., 2012. EEG delta oscillations as a correlate of basic homeostatic and motivational processes. Neurosci. Biobehav. Rev. 36, 677695.

KuCEWICZ M. T., TRICKLEBANK M. D., BogaCZ R., JONES M. W., 2011. Dysfunctional prefrontal cortical network activity and interactions following cannabinoid receptor activation. J. Neurosci. 31, 15560-15568.

LANDFIELD P. W., CADWALladeR L. B., VINSANT S., 1988. Quantitative changes in hippocampal structure following long-term exposure to $\Delta 9$ tetrahydrocannabinol: possible mediation by glucocorticoid systems. Brain Res. 443, 47-62.

LAPREVOTE V., BON L., KRIEG J., SCHWITZER T., BOURION-BEDES S., MAILlaRD L., SCHWAN R., 2017. Association between increased EEG sig- 
nal complexity and cannabis dependence. Eur. Neuropsychopharmacol. 27, 1216-1222.

Laufs H., Krakow K., STERZer P., Eger E., BeyERLE A., SAlEK-HADDADI A., KLEINSChMIDT A., 2003. Electroencephalographic signatures of attentional and cognitive default modes in spontaneous brain activity fluctuations at rest. Proc. Natl. Acad. Sci. USA 100, 11053-11058.

Ligresti A., Cascio M. G., Pryce G., Kulasegram S., Beletskaya I., De Petrocellis L., BaKeR D., 2006. New potent and selective inhibitors of anandamide reuptake with antispastic activity in a mouse model of multiple sclerosis. Brit. J. Pharmacol. 147, 83-91.

LISMAN J., IDIART M., 1995. Storage of $7+/-2$ short-term memories in oscillatory subcycles. Science 267, 1512-1515.

LlinÁS R., Ribary U., CONTRERAS D., PEDROARENA C., 1998. The neuronal basis for consciousness. Philosoph. Transact. Royal Soc. London, B Biol. Sci. 353, 1841-1849.

LORENZETTI V., SOLOWIJ N., YÜCEL M., 2016. The role of cannabinoids in neuroanatomic alterations in cannabis users. Biol. Psychiatry 79, e17-e31.

LuKas S. E., MENDELson J. H., BenedikT R. 1995. Electroencephalographic correlates of marihuana-induced euphoria. Drug Alcohol Depend. 37, 131-140.

MailleuX P., VANDERHAEGHen J. J., 1992. Distribution of neuronal cannabinoid receptor in the adult rat brain: a comparative receptor binding radioautography and in situ hybridization histochemistry. Neuroscience 48, 655-668.

MANZANARES J., CORCHERO J., ROMERO J., FERNANDEZ-RUIZ J. J., RAMOS J. A., FUENTES J. A., 1998. Chronic administration of cannabinoids regulates proenkephalin $m R N A$ levels in selected regions of the rat brain. Mol. Brain Res. 55, 126-132.

Mechoulam R., Parker L. A., Gallily R., 2002. Cannabidiol: an overview of some pharmacological aspects. J. Clin. Pharmacol. 42, $11 \mathrm{~S}-19 \mathrm{~S}$.

Metrik J., Kahler C. W., Reynolds B., McGeary J. E., Monti P. M., Haney M., Rohsenow D. J., 2012. Balanced placebo design with marijuana: pharmacological and expectancy effects on impulsivity and risk taking. Psychopharmacology 223, 489-499.

Morgan C. J. A., Freeman T. P., Powell J. C. H. V., CURRAN H. V., 2016. AKT1 genotype moderates the acute psychotomimetic effects of naturalistically smoked cannabis in young cannabis smokers. Translat. Psychiatry 6, e738.

PACHer P., BÁtKai S., Kunos G., 2006. The endocannabinoid system as an emerging target of pharmacotherapy. Pharmacol. Rev. 58, 389462.

Palva S., PAlVA J., 2007. New vistas for alpha-frequency band oscillations. Trends Neurosci. 30, 150-158.

Palva S., LinkenKaER-Hansen K., NAATANEN R., PALVA J., 2005. Early neural correlates of conscious somatosensory perception. J. Neurosci. 25, 5248-5258.

Pfurtscheller G., Stancak JR, A., Neuper C., 1996. Event-related synchronization (ERS) in the alpha band - an electrophysiological correlate of cortical idling: a review. Int. J. Psychophysiol. 24, 39-46.

PfuRTSheller G., DA Silva F. L., 1999. Handbook of electroencephalography and clinical neurophysiology, revised series. Amsterdam: Elsevier Science B.V.
PisAnu A., ACQuas E. L. I. O., Fenu S., Di ChIARA G., 2006. Modulation of $\triangle 9$-THC-induced increase of cortical and hippocampal acetylcholine release by $\mu$ opioid and $D 1$ dopamine receptors. Neuropharmacology 50, 661-670.

Pistis M., Muntoni A. L., Pillolla G., Gessa G. L., 2002. Cannabinoids inhibit excitatory inputs to neurons in the shell of the nucleus accumbens: an in vivo electrophysiological study. Eur. J. Neurosci. 15, 1795-1802.

Pollan M., 2001. The Botany of Desire Random House. Inc., New York.

PRASHAD S., DEDRICK E. S., FIlbey F. M., 2018. Cannabis users exhibit increased cortical activation during resting state compared to non-users. NeuroImage 179, 176-186.

PUTMAN P., 2011. Resting state EEG delta-beta coherence in relation to anxiety, behavioral inhibition, and selective attentional processing of threatening stimuli. Int. J. Psychophysiol. 80, 63-68.

RAICHLE M., 2010. Two views of brain function. Trends Cognit. Sci. 14, 180-190.

Raver S. M., Keller A., 2014. Permanent suppression of cortical oscillations in mice after adolescent exposure to cannabinoids: receptor mechanisms. Neuropharmacology 86, 161173.

Raver S. M., Haughwout S. P., Keller A., 2013. Adolescent cannabinoid exposure permanently suppresses cortical oscillations in adult mice. Neuropsychopharmacology 38, 2338.

RoBBE D., BuzSÁKI G., 2009. Alteration of theta timescale dynamics of hippocampal place cells by a cannabinoid is associated with memory impairment. J. Neurosci. 29, 12597-12605.

RobBe D., Montgomery S. M., ThOMe A., RueDA-OROzCO P. E., MCNAUGHTON B. L., BuZsÁKI G., 2006. Cannabinoids reveal importance of spike timing coordination in hippocampal function. Nat. Neurosci. 9, 1526.

Russo E., GuY G. W., 2006. A tale of two cannabinoids: the therapeutic rationale for combining tetrahydrocannabinol and cannabidiol. Med. Hypotheses 66, 234-246.

Russo E. B., Burnett A., Hall B., Parker K. K., 2005. Agonistic properties of cannabidiol at 5-HT1a receptors. Neurochem. Res. 30, 10371043.

SALENIUS S., HARI R., 2003. Synchronous cortical oscillatory activity during motor action. Curr. Opin. Neurobiol. 13, 678-684.

SAlEs-CARBONEll C., RUEdA-OROZCO P. E., Soria-Gómez E., Buzsáki G., Marsicano G., RobBe D., 2013. Striatal GABAergic and cortical glutamatergic neurons mediate contrasting effects of cannabinoids on cortical network synchrony Proc. Natl. Acad. Sci. USA 110, 719-724.

SANES J., DONOGHUE J., 1993. Oscillations in local field potentials of the primate motor cortex during voluntary movement. Proc. Natl. Acad. Sci. USA 90, 4470-4474.

Sauseng P., Klimesch W., Schabus M., DoppelMAYR M., 2005. Fronto-parietal EEG coherence in theta and upper alpha reflect central executive functions of working memory. Int. J. Psychophysiol. 57, 97-103.

Scallet A. C., Uemura E., Andrews A., Ali S. F., Mcmillan D. E., Paule M. G., SlikKer JR W., 1987. Morphometric studies of the rat hippocampus following chronic delta-9-tetrahydrocannabinol (THC). Brain Res. 436, 193-198.

Sañudo-Peña M. C., PATRICK S. L., KHEN S., PATRICK R. L., TSOU K., WALKER J. M., 1998. Cannabinoid effects in basal ganglia in a rat 
model of Parkinson's disease. Neurosci. Lett. 248, 171-174.

Scheeringa R., BastiaAnsen M. C., Petersson K. M., OOSTENVEld R., NORRIS D. G., HAGOORT P., 2008. Frontal theta EEG activity correlates negatively with the default mode network in resting state. Int. J. Psychophysiol. 67, 242251.

SCHLICKER E., TIMM J., ZENTner J., GÖTHERT M., 1997. Cannabinoid CB1 receptor-mediated inhibition of noradrenaline release in the human and guinea-pig hippocampus. Naunyn-Schmiedeberg's Arch. Pharmacol. 356, 583-589.

SHEN M., PISER T. M., SEYBOld V. S., ThAYER S. A., 1996. Cannabinoid receptor agonists inhibit glutamatergic synaptic transmission in rat hippocampal cultures. J. Neurosci. 16, 43224334.

Skosnik P., Krishnan G., D'souza D., HeTrick W., O'DONNELL B., 2014. Disrupted gamma-band neural oscillations during coherent motion perception in heavy cannabis users. Neuropsychopharmacology 39, 3087.

Soltesz I., Alger B., Kano M., Lee S., LovingeR,D., OHNO-ShosakU T., WATANABE M., 2015. Weeding out bad waves: towards selective cannabinoid circuit control in epilepsy. Nat. Rev. Neurosci. 16, 264-277.

STElla N., 2004. Cannabinoid signaling in glial cells. Glia 48, 267-277.

STRUVE F. A., STRAUMANIS J. J., PATRICK G., 1994. Persistent topographic quantitative EEG sequelae of chronic marihuana use: a replication study and initial discriminant function analysis. Clin. Electroencephalogr. 25, 63-75.

STRUVE F. A., PATRICK G., STRAumANis J. J., Fitz-Gerald M. J., MANno J., 1998. Possible EEG sequelae of very long duration marihuana use: pilot findings from topographic quantitative EEG analyses of subjects with 15 to 24 years of cumulative daily exposure to THC. Clin. Electroencephalogr. 29, 31-36.
Struve F. A., Straumanis J. J., Patrick G., LeAVITT J., MANNO J. E., MANNO B. R., 1999. Topographic quantitative EEG sequelae of chronic marihuana use: a replication using medically and psychiatrically screened normal subjects. Drug Alcohol Depend. 56, 167-179.

TANDA G., PONTIERI F. E., DI CHIARA G., 1997. Cannabinoid and heroin activation of mesolimbic dopamine transmission by a common $\mu 1$ opioid receptor mechanism. Science 276, 2048-2050.

VARELA F., LACHAUX J. P., RODRIGUEZ E. MARTINERIE J., 2001. The brainweb (phase synchronization and large-scale integration). Nat. Rev. Neurosci. 2, 229-239.

Valverde O., Noble F., Beslot F., Daugé V., FoURNiÉ-ZALUSKI M. C., RoQues B. P., 2001. $\Delta 9$ tetrahydrocannabinol releases and facilitates the effects of endogenous enkephalins: reduction in morphine withdrawal syndrome without change in rewarding effect. Eur. J. Neurosci. $13,1816-1824$.

VINOGRADOVA O., 1995. Expression, control, and probable functional significance of the neuronal theta-rhythm. Prog. Neurobiol. 45, 523583.

YÜCEL M., LuBMAN D. I., SOlOWIJ N., BREWER W. J., 2007. Understanding drug addiction: a neuropsychological perspective. Aust. NZ J. Psychiatry 41, 957-968.

WRÓBEL A., 2000. Beta activity: a carrier for visual attention. Acta Neurobiol. Exp. 60, 247260.

Zimmermann T., Bartsch J. C., Beer A., LOMAZZO E., GugGenHuber S. i współaut., 2019. Impaired anandamide/palmitoylethanolamide signaling in hippocampal glutamatergic neurons alters synaptic plasticity, learning, and emotional responses. Neuropsychopharmacology 44, 1377-1388.

KOSMOS Vol. 69, 1, 219-232, 2020

AlicJA BinkowskA ${ }^{1}$, ANETA BRZEZICKA ${ }^{1,2}$

${ }^{1}$ Faculty of Psychology, SWPS University of Social Sciences and Humanities, 19/31 Chodakowska Str., 03-815 Warsaw, O²Cedars-Sinai Medical Center, 8700 Beverly Blvd, Los Angeles, CA 90048, USA,

E-mail: abinkowska2@st.swps.edu.pl; Aneta.Brzezicka@cshs.org

EFFECTS OF MARIJUANA ON BRAIN ELECTRICAL ACTIVITY

Sum mary

Marijuana is one of the most popular and most frequently taken psychoactive substance in the world. There are over 140 different cannabinoids in cannabis, of which the best known are $\Delta 9$-tetrahydrocannabinol (THC) and cannabidiol $(\mathrm{CDB})$. Cannabinoids impact the endocannabinoid system, which plays a crucial role in maintaining the homeostasis of the human body and other processes as neuroplasticity. The aim of the article is to introduce a reader to the current knowledge of the effects of marijuana on biochemical processes and electrical brain activity in animals and humans. According to research findings cannabis alter the brain's electrical activity in humans, both when the person is directly affected by the substance and by a long-term use. Moreover, the animal studies allow us to better understand the mechanisms underlying the effects of cannabis on neuronal oscillations.

Key words: EEG, endocannabinoid system, marijuana, neural oscillations, THC 